\title{
O NORMIE I KONWENCJI ARTYSTYCZNEJ - WYBRANE ZAGADNIENIA NIEPRZETŁUMACZALNOŚCI NA PRZYKŁADZIE SZTUKI
}

\begin{abstract}
Zarys treści: Język sztuki jest specyficznym gatunkiem tekstu, posługującym się nie tylko przyjętymi normami językowymi, lecz także indywidualnymi konwencjami artystycznymi. Translacja tychże tekstów wymaga od tłumacza z jednej strony oczywistych kompetencji językowych, z drugiej zaś wyczucia osobistego stylu, formy, środków i estetyki przekazu, jakimi posługuje się dany twórca - artysta. Niniejszy artykuł analizuje wybrane aspekty nieprzetłumaczalności i braku ekwiwalencji w tekstach z zakresu sztuki (malarstwo, rzeźba, grafika, performance, video-art itp.), odnosząc je do współczesnych teorii translatorycznych. Kontakt $z$ artystą lub kontemplacja samego dzieła powinna być zatem traktowana jako nieodłączny element pracy tłumacza tekstów o specyfice artystycznej.
\end{abstract}

Słowa kluczowe: tłumaczenie, tłumaczenie sztuki, konwencja artystyczna, język sztuki

$\mathrm{W}$ Polsce lat dziewięćdziesiątych ubiegłego wieku, w dobie gwałtownego wzrostu zapotrzebowania na usługi pośredników językowych, kulturowych i komunikacyjnych, codziennym udziałem tłumaczy specjalistycznych było informowanie ludzi nieznających języka polskiego o zachodzących w naszym kraju przemianach politycznych, prawnych, kulturalnych i gospodarczych, rodaków zaś - o realiach innych krajów, których obywatele zaczęli coraz liczniej napływać do Polski w ramach wymiany handlowej, artystycznej lub po prostu turystycznej. Zarówno więc thumacze prawniczy, współpracujący z adwokatami, dużymi spółkami i małymi firmami, jak i tłumacze przysięgli, działa- 
jący na zlecenie sądów, policji, galerii sztuki i innych dzielnie zmagali się z powierzonymi im działaniami, mimo niedostatecznej ilości literatury na temat metodologii thumaczeń specjalistycznych. Sami więc zaczęli opracowywać metody thumaczenia tychże tekstów.

Głębokie zmiany ustrojowe, jakie przeżył nasz kraj od początku lat dziewięćdziesiątych, doprowadziły do bardzo istotnych zmian w systemach: ekonomicznym, prawnym, administracyjnym, w instytucjach, a przede wszystkim w kulturze i sztuce. $Z$ jednej strony było to podyktowane restrukturyzacją wielu sfer życia społecznego, z drugiej dążnością do dostosowania pewnych zjawisk życia do standardów europejskich. Powstały zatem nie tylko nowe instytucje, których funkcjonowanie regulują nowe „teksty”, o charakterze prawniczym czy ekonomicznym, ale również thumacz stara się naśladować pewne formy medialne, odpowiadające normom europejskim.

Według współczesnych teorii translatorycznych dokładność tłumaczenia rozpatrywana jest pod względem wierności i poprawności merytorycznej przekładu. Tłumaczenie powinno odpowiadać oryginałowi. Tłumaczyć należy cały tekst i tylko tekst. Przy thumaczeniu należy pamiętać, że podstawą translacji wszystkich terminów specjalistycznych powinien być glosariusz, a raz przyjęte tłumaczenie używać konsekwentnie przez cały czas. Należy stosować zasadę DOUBLE-CHECK, a więc każdy nowy termin należy sprawdzać co najmniej i dwóch różnych źródłach (www.lomac.net).

W niniejszym artykule będę rozpatrywała dwa pojęcia: normy językowej i konwencji artystycznej, dlatego też postanowiłam pokrótce przybliżyć znaczenie tych niejako ściśle ze sobą związanych i obowiązujących w translacji terminów.

Normą określona jest wszelka wypowiedź dotycząca tego, co „powinno” być, w szczególności zaś wyrażająca wskazanie (zalecenie, dyrektywę) określonego sposobu postępowania w konkretnej sytuacji. Każda norma wyznacza obowiązek (powinność) takiego a nie innego zachowania się w danych warunkach w celu spowodowania stanu rzeczy uznanego za pozytywny lub pożądany ze względu na przyjęte wartości. Postępowanie niezgodne z normami wiąże się zwykle z określonymi sankcjami (Encyklopedia Powszechna t. 3, 1975: 297). W odniesieniu do normy językowej oznacza to konieczność przetłumaczenia tekstu poprawną polszczyzną, zachowanie przejrzystości, zwięzłości, spójności logicznej, a przede wszystkim zadbanie, aby thumaczenie było zrozumiałe dla odbiorcy. Zdania powinny brzmieć naturalnie, język nie powinien być zbyt potoczny lub oficjalny (w zależności od rodzaju tekstu), należy stosować polityczną poprawność obowiązującą w Polsce. 
Natomiast zespół przyjętych norm postępowania, myślenia w szerokim tego słowa znaczeniu, bądź też umowność, maniera cechująca utwór artystyczny lub twórczość oznacza przyjętą konwencję (Encyklopedia Powszechna t. 2, 1975: 547). Konwencja językowa zgodna jest z realiami języka docelowego: odniesienia (np. geograficzne, regionalne, administracyjne), formaty, standardy itp. (www.lomac.net).

Język sztuki jest specyficznym gatunkiem tekstu, posługującym się nie tylko przyjętymi normami językowymi, lecz także indywidualnymi konwencjami artystycznymi. Translacja tychże tekstów wymaga od tłumacza z jednej strony oczywistych kompetencji językowych, z drugiej zaś wyczucia osobistego stylu, formy, środków wyrazu i estetyki przekazu, jakimi posługuje się dany twórca - artysta. Co rozumiane jest zatem pod pojęciem sztuki?

Sztuka jako podstawowy składnik kultury, jako jeden ze sposobów uzewnętrzniania zdolności twórczych człowieka jest zespołem świadomych działań ludzkich, w wyniku których powstaje przedmiot estetyczny (np. obraz, rzeźba, budowla, film, utwór muzyczny bądź sceniczny), określany mianem dzieła lub dzieła sztuki. Zakres znaczeniowy pojęcia „sztuka” zmieniał się w ciągu stuleci. W starożytności był on rozległy: greckim słowem téchne (od niego wywodzi się współczesny termin „technika”) i łacińskim ars (dało początek nazwom sztuki w większości języków europejskich) określano szeroko rozumianą umiejętność wykorzystywania rzeczy według pewnych reguł estetycznych, a więc poza malarstwem czy rzeźbą lub rzemiosłem zaliczano do sztuki również aktywność poznawczą człowieka - filozofię. W okresie renesansu, częściowo dzięki pogłębionej refleksji estetyczno-filozoficznej, eksponującej rolę piękna (np. M. Ficino), wzrosła świadomość wspólnoty łączącej malarstwo, rzeźbę i architekturę, powodując ok. połowy XVII wieku ich oddzielenie od rzemiosła. Wkrótce nastąpił też ostateczny rozłam twórczości artystycznej i nauki, wykrystalizowała się dziedzina sztuk pięknych, która obok wymienionych wyżej sztuk plastycznych obejmowała muzykę, taniec, poezję, wymowę i aktorstwo. Przez cały wiek XIX uważano sztukę za naśladowanie natury przez wybieranie z niej tego, co piękne. Dokonywano rozpoznawania prawideł rządzących jej rozwojem, określania związków z całością życia społeczno-politycznego poszczególnych epok i psychologicznych, a następnie socjologicznych aspektów. Wiek XX wprowadził w obręb sztuk nowe dziedziny, m.in. film, fotografię, performance, video-art, jak również rozmaite formy z pogranicza wielu dziedzin, np. happening. Zakwestionował także konstytutywną rolę piękna w sztuce, eksponując rolę brzydoty jako kategorii estetycznej. Władysław Tatarkiewicz sformułował definicję sztuki jako odtwarzanie, konstruowanie rzeczy. Zadaniem zdolnych 
jest więc zachwycać, wzruszać lub wstrząsać (Popularna Encyklopedia Powszechna t. 17, 1997: 280).

Jako tłumacz tekstów o tematyce artystycznej zdaję sobie sprawę, iż jestem pośrednikiem komunikacyjnych kompetencji translatorskich, które polegają na umiejętności tworzenia w języku obcym tekstów ekwiwalentnych oryginałowi, z uwzględnieniem uwarunkowań komunikacyjnych. Działanie to zakłada umiejętność kontrastywnego zestawienia elementów kultur towarzyszących językowi obcemu i ojczystemu.

Kulturę danej społeczności tworzy według B. Kielar kompletny model sposobu życia, z którego jednostka w sposób selektywny opanowuje pewne aspekty, w zależności od swej przynależności do grup według płci, wieku, zawodu itp. (Kielar 1989: 52).

W komunikacji należy nawiązywać do ogólnej wiedzy, wierzeń, zwyczajów, zakazów, kodów, instytucji, narzędzi, technik, dzieł sztuki, rytuałów, ceremonii. W wyniku kontaktów informacje kulturowe przepływają z jednej społeczności kulturowej do drugiej. Owa dyfuzja kulturowa zachodzi przede wszystkim w ramach tzw. kultury masowej, przy której występuje wysoki stopień standaryzacji i niezwykle szeroki zakres oddziaływania społecznego. Kontakt z obcą kulturą wywołuje zazwyczaj przyswojenie tej kultury, a więc zmiany w naszej świadomości, określane mianem akulturacji (Kielar 1989: 52-55).

Podczas tłumaczenia interpretacje zjawisk kulturowych języka obcego i ojczystego wiążą się z poszukiwaniem ekwiwalentnych środków wyrazu w języku docelowym. Tak więc thumacząc tekst o specyfice artystycznej, należy bardzo dobrze znać jego dziedzinę, charakteryzować się wyczuciem piękna i estetyki. Tłumaczenie tego typu tekstów często powinno sprowadzić się do odnalezienia ekwiwalentów kontekstowych (wyrażeń, sformułowań), które występują w tekstach paralelnych $w$ języku wyjściowym. Tłumacz nie ryzykuje stworzenia wyrażenia nienaturalnego czy obcego w danym modelu, a zastąpi je najbardziej naturalnym odpowiednikiem kontekstowym, przy czym jako kontekst należy tu pojmować odpowiedni model tekstu, który akceptuje dane wyrażenie. Zdarza się często, że dany model w kulturze docelowej w ogóle nie istnieje, jak np. pojęcie „Solidarność” lub „wydarzenia bydgoskie”. Tłumacz stoi wówczas przed koniecznością stworzenia nowego typu tekstu, nie istniejącego w kulturze docelowej, ale który może mieć już długą tradycję w kulturze wyjściowej. W tym momencie to nie przekładoznawstwo czerpie z doświadczeń tekstologii kontrastywnej, jest ona natomiast narzędziem ułatwiającym powstawanie nowych typów tekstów w danym społeczeństwie (Tomaszkiewicz 2002: $13-15)$. 
Trudności przekładowe tekstów z dziedziny sztuki często nie wynikają z problemów terminologicznych, a ile $\mathrm{z}$ różnic $\mathrm{w}$ realiach dwóch kultur wchodzących we wzajemne kontakty. Istnieją wyrażenia, które w języku polskim tworzą swego rodzaju grę słów, jak choćby pojęcie „zdarzenie/zdarzenia bydgoskie”. Margines kreatywności tłumacza jest w tym przypadku niewielki, gdyż połączenie obydwu słów adekwatnych w języku niemieckim nie miałoby jakiegokolwiek głębszego znaczenia. Ewentualne thumaczenie musi zatem uwzględniać różnice kulturowe, słowotwórcze, leksykalne, inną symbolikę czy też system wartości. W każdej operacji przekładu działania tłumacza nie mogą być zatem automatyczne. Musi on zdawać sobie sprawę z różnic i podobieństw między modelami tekstów, które powinien zestawić w procesie thumaczenia. Jest to zatem pewna forma mediacji między modelami tekstów.

Jerzy Jarniewicz w artykule Tłumacz jako twórca kanonu dokonuje podziału thumaczy na dwie grupy. Do jednej z nich zaliczany jest tłumacz „ambasador”, który w swoich przekładach nie próbuje ustanawiać własnych hierarchii wartości, przeciwnie - przygląda się temu, co w kulturze, z której tłumaczy, uchodzi za najlepsze, najciekawsze, śledzi to, co ową kulturę współkształtuje. Do takich thumaczy należał chociażby Maciej Słomczyński, który poświęcił parę lat życia na przekład najważniejszego tekstu europejskiego modernizmu - Ulissesa J. Joyce'a. Drugim gatunkiem thumacza jest tłumacz „legislator”, który z kolei reprezentuje pogląd, iż jego przekład może wejść w twórczy dialog z np. literaturą rodzimą, proponując jej nowe wzorce, języki, nowe kryteria. Tłumacz ten obok normy stosuje także własną konwencję twórczą, tworzy własne artystyczne prawo (Jarniewicz 2002: 36-38).

Osobiste wybory tłumacza skłaniają do refleksji nad możliwościami i ograniczeniami polskiego i niemieckiego modelu języka artystycznego. Podczas prac translatorskich nad dziełami jednej z bydgoskich artystek spotkałam się z wytycznymi, o których artystka poinformowała mnie osobiście. Tłumaczenie dotyczyło obrazu zatytułowanego: „Jestem”, który można byłoby przełożyć po prostu jako: „Ich bin”. Jednakże znająca język docelowy malarka nie wyraziła zgody na takowe thumaczenie. Nasuwa się więc pytanie: czy przy tłumaczeniu dzieł sztuki nie należałoby stale kontaktować się z autorem dzieła? W większości przypadków jest to niestety już niemożliwe. Na własne ryzyko thumaczymy więc tytuły obrazów, rzeźb, reliefów, grafik, miedziorytów, akwafort, fotografii, filmów, pokazów sztuki performance itp., zgodnie z wyznawanym systemem wartości i posiadaną wiedzą z danej dziedziny. Nasz wybór powinien być reprezentatywny dla konkretnego dzieła sztuki. Dany przekład należy uznać za zjawisko kultury, a wszelkie odmienności językowe, kulturowe, religijne czy też aksjologiczne należy rozumieć jako możliwość przyswojenia, pokonania 
bariery językowej i kulturowej. Przekład o specyfice artystycznej jest thumaczeniem zaspokajającym filozoficzno-poznawcze, estetyczne i etyczne potrzeby człowieka.

Należy liczyć się również z faktem zaistnienia ryzyka szoku kulturowego, wywołanego czytaniem przekładu. Jednocześnie istnieje też dążenie przeciwstawne: do poznania rzeczy nowych, poznania świata, który różni się od tego, co codzienne i swojskie. Taką postawę możemy zaobserwować u odbiorców akceptujących obcość przekładu. Obie cechy odbieranego tekstu intrygują ich, postrzegane powinny być jako oryginalne i ciekawe (Lewicki 2002: 41-45).

Właśnie ciekawość świata jest tą cechą człowieka, a więc i odbiorcy przekładu, która z reguły skłania go do sięgnięcia po przekład. Świadczy to o pewnej aktywności poznawczej odbiorców tłumaczenia.

Nietrudno zauważyć, że postrzeganie obcości ludzi i grup ludzkich związane jest $\mathrm{z}$ istnieniem pożytecznych kontaktów społecznych pomiędzy oceniającymi a ocenianymi. Podobnie odbiór obcości w przekładzie zależny jest od stanu kontaktów między obu społecznościami, z czym wiąże się znajomość obcej kultury, wyznaczająca tzw. ograniczoną dwukulturowość, a więc znajomość jego języka, przyjmującą najczęściej postać znajomości tylko niektórych jego faktów: wyrażeń, zachowań językowych w określonych sytuacjach komunikacyjnych, nazw własnych itp., wyznaczająca tzw. ograniczony bilingwizm odbiorców. Owa obcość thumaczonego tekstu stanowi istotny wyznacznik konwencji odbioru przekładu, kształtując normę przekładu, nieidentyczną z normą dla tekstów niebędących przekładami. Konwencja odbioru oryginału i konwencja odbioru przekładu nigdy nie są tożsame. Odbiorca oczekuje czasami pojawienia się w danym przekładzie elementów o obcym rodowodzie, np. obcych imion własnych. Bliskość tych konwencji odbioru jest oczywiście możliwa, lecz zależy ona od wspomnianego już stanu kontaktów między obiema społecznościami, a nie, jak to się czasami sądzi, od pokrewieństwa obiema języków. Dystans pomiędzy obu kulturami jest zmienny w czasie, ponieważ jest on funkcją aktualnego ich usytuowania wobec siebie, stanu i intensywności ich wzajemnych kontaktów, dalej historycznych zadrażnień i resentymentów, wzajemnego zaciekawienia i fascynacji (Lewicki 2002: 49-52).

Znajomość kultur języka docelowego i tłumaczonego pozwala thumaczowi dynamicznie interpretować tekst również w zależności od celu tłumaczenia. W translacji o specyfice artystycznej thumacz porusza się pomiędzy dwoma biegunami. Pierwszy biegun wyznacza norma językowa, której thumacz musi przestrzegać, drugi zaś stanowi konwencja. Niestety jest ona z reguły ograniczona prywatnością artysty, jego osobistymi życzeniami lub regułami gramatycznoleksykalnymi, bądź po prostu nieprzetłumaczalnością. Prostym przykładem 
może być tytuł obrazu jednego z mistrzów niemieckiej sztuki współczesnej: „Paradies - Versuche”, który można byłoby przełożyć na język polski według mnie przynajmniej trojako. Zarówno jako: „Próby osiągnięcia raju” oraz jako „Raj - kuszenie” lub „W drodze do raju”. W tym momencie istnieje konieczność osobistej konfrontacji tłumacza $\mathrm{z}$ dziełem, przegląd katalogów z twórczością artysty, aby móc w stu procentach oddać wierność przekazu. Niezachowanie konwencji językowej lub też jej niezamierzone wypaczenie (gdyż zamierzone uznać można za świadomy zabieg estetyczno-translatorski) może doprowadzić do efektów komicznych. W przypadku tytułu miedziorytu „Gefallene Früchte oder preußische Großmutter" natrafić można na dylemat translatorski, polegający na przekładzie dwóch pierwszych elementów: „Gefallene Früchte...” Posłużenie się ekwiwalentem dosłownym „spady” (właściwym dla terminologii przetwórstwa przemysłowego) nadaje całości wymiar komiczny. Posłużyć się więc należałoby innymi, bardziej dostępnymi, jednakże opisowymi ekwiwalentami (jak choćby: „opadłe owoce” lub „owoce opadłe z drzewa”), nadającymi tytułowi dzieła odmienny charakter.

Konkludując: podczas przekładu tekstów o specyfice artystycznej zaobserwować można, w odróżnieniu od tekstów typowo technicznych, prawniczych, handlowych czy administracyjnych, wielorakie dyferencje. Przy pismach prawniczych czy też technicznych zastosowane zostaje tłumaczenie bliższe i wierne oryginałowi, a więc thumaczenie typowo dosłowne. Wszystkie rodzaje owych tekstów posługują się właściwymi, specyficznymi dla siebie konwencjami. Zastosowanie dosłownego thumaczenia przy tekstach o tematyce artystycznej doprowadziłoby z pewnością do rozbicia konwencji artystycznej, zniszczyłoby poczucie estetyki, która jest nieodzownym elementem tychże pism. Podsumowując należałoby stwierdzić, iż konwencja w tekstach o tematyce artystycznej jest niedefiniowalna, nieuchwytna, jest zabiegiem chwilowym, ma indywidualny charakter, związany z estetyką twórcy - artysty, z jego osobistymi pragnieniami i zaleceniami. Uznać więc należy, że kompetencje thumacza owych tekstów nieodłącznie związane są z zaistnieniem trudności w określeniu zespołu umiejętności, jakimi dany tłumacz powinien się charakteryzować. Kontakt $\mathrm{z}$ artystą lub kontemplacja samego dzieła powinny być traktowane jako nieodłączny element pracy tłumacza tekstów o specyfice artystycznej. Szerokie spektrum zainteresowań tematyką nie tylko z dziedziny sztuki obejmować powinno zaś zakres badawczy pracy tłumaczy. 


\section{Literatura}

Encyklopedia Powszechna PWN, t. 3 i 2 1975, Warszawa.

Jarniewicz, J. 2002, Ttumacz jako twórca kanonu, [w:] Przekład-JęzykKultura, red. R. Lewicki, Lublin.

Kielar, B. 1989, Sposoby interpretacji zjawisk kulturowych przy nauczaniu języka obcego oraz tlumaczeniu, [w:] Bilingwizm, bikulturyzm, implikacje glottodydaktyczne. Materiały z XII Sympozjum zorganizowanego przez Instytut Lingwistyki Stosowanej Uniwersytetu Warszawskiego, red. F. Grucza, Warszawa.

Lewicki, R. 2002, Obcość w przektadzie, a obcość w kulturze, [w:] Kultura, Lublin.

Popularna Encyklopedia Powszechna, t. 17, 1997, Warszawa.

Tomaszkiewicz, T. 2002, Transfer $i$ adaptacja nowych modeli tekstów poprzez operacje przekładu, [w:] Przekład - Jezzyk - Kultura, red. R. Lewicki, Lublin.

www.lomac.net

\section{Language norms and artistic conventions - selected difficulties which may appear while translating artistic texts}

\section{Summary}

The language of art is a specific sort of linguistics which uses not only language norms but also individual artistic conventions. Several language skills are required from the translator as well as individual feeling for the style, form and means of expression used by the artist. This article analyses certain difficulties which may appear while translating artistic texts, such as, for instance, lack of translation possibilities referring to modern theories of translation, along with the need for equivalent vocabulary connected with art (painting, sculpture, graphic, performance, video-art etc.). What seems to be of crucial importance is that the contact with the artist and deep study of his art should be treated as an inseparable element of translation.

Keywords: translation, art translation, artistic convention, language of art 